\title{
Multiple Inherited Thrombophilias in a Young Patient with Striatocapsular Stroke
}

Sir,

The association between inherited thrombophilias and arterial acute ischemic stroke (AIS) has not been definitely established. ${ }^{[1]}$ Coexistence of inherited thrombophilia with other prothrombotic conditions in cerebral vein thrombosis is not rare $^{[2]}$ and suggests a dose-response 


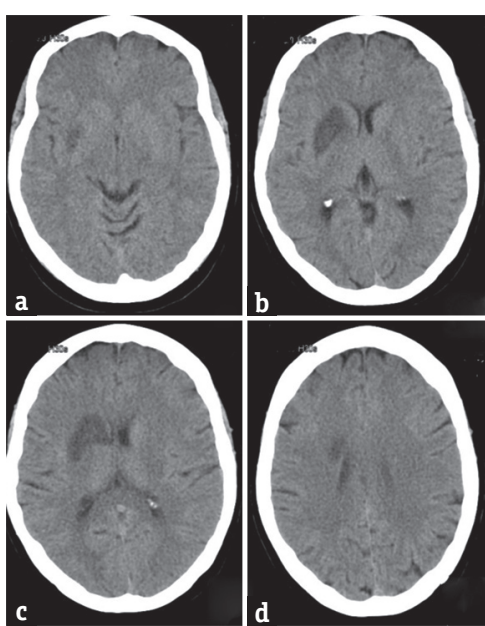

Figure 1: (a-d) Brain computed tomography showing a comma-shaped (1C) right striatocapsular infarcts involving the caudate, anterior limb of internal capsule, and putamen

relationship. Whether the same thrombotic gradient risk applies to AIS is speculative. We present a case of a 46-year-old female, without any vascular risk factors, admitted to the hospital after wake-up onset of left-sided hemiparesis and hemihypesthesia. A striatocapsular ischemic stroke was documented on brain computed tomography (CT) [Figure 1]. Her mother had suffered an AIS of undetermined type (incomplete investigation) at the age of 60 years and her sister had suffered recurrent episodes of deep vein peripheral thromboembolism by the age of 26 years, in association with heterozygous factor $\mathrm{V}$ Leiden mutation. The extensive cerebrovascular investigation, including transesophageal echocardiography, Holter monitoring, cervical/intracranial Doppler, and cervical/intracerebral angio-CT, yielded negative results. The screen for thrombophilia performed at the National Reference Laboratory revealed the presence of heterozygous factor V G1691A (Leiden), methylenetetrahydrofolate reductase (MTHFR) C677T, and MTHFR A1298C polymorphisms. A clinical decision to start warfarin was made (INR 2-3). She recovered progressively and regained her previous activities (modified Rankin 0) 3 months after being discharged. Striatocapsular infarct is a distinct subgroup of subcortical stroke. ${ }^{[3]}$ Our patient suffered a complete striatocapsular stroke, which, in the absence of middle cerebral artery disease, is most likely of embolic origin. ${ }^{[4]}$ Although rarely considered to be causative of AIS in adults, hypocoagulation is considered as a valid treatment in the presence of thrombophilias. ${ }^{[5]}$ The association between each of the thrombophilias found (when isolated) with AIS is weak. ${ }^{[1,6]}$ However, we believe that the prothrombotic synergism caused by the simultaneous presence of three inherited thrombophilias most probably explains the occurrence of ischemic stroke in this young patient.

\section{Financial support and sponsorship}

Nil.

\section{Conflicts of interest}

There are no conflicts of interest.

\section{Isabel Taveira ${ }^{l}$, Cláudia Vicente ${ }^{l}$, Sofia Sobral ${ }^{1}$,} Hipólito Nzwalo ${ }^{1,2}$, José Sousa E Costa

${ }^{1}$ Internal Medicine Department, Stroke Unit, Litoral Alentejano Hospital, Santiago do Cacém, ${ }^{2}$ Department of Biomedical Sciences and Medicine, University of Algarve, Faro, Portugal

Address for correspondence: Dr. Isabel Taveira, Litoral Alentejano Hospital, EPE. Monte do Gilbardinho, 7540-230 Santiago do Cacém, Portugal. E-mail: isabeltaveira89@gmail.com

\section{REFERENCES}

1. de Lau LM, Leebeek FW, de Maat MP, Koudstaal PJ, Dippel DW. A review of hereditary and acquired coagulation disorders in the aetiology of ischaemic stroke. Int J Stroke 2010;5:385-94.

2. Ferro JM, Canhão P, Stam J, Bousser MG, Barinagarrementeria F; ISCVT Investigators. Prognosis of cerebral vein and dural sinus thrombosis: Results of the International Study on Cerebral Vein and Dural Sinus Thrombosis (ISCVT). Stroke 2004;35:664-70.

3. Donnan GA, Bladin PF, Berkovic SF, Longley WA, Saling MM. The stroke syndrome of striatocapsular infarction. Brain 1991;114(Pt 1A):51-70.

4. Jung S, Hwang SH, Kwon SB, Yu KH, Lee BC. The clinico-radiologic properties of deep small basal ganglia infarction: Lacune or small striatocapsular infarction? J Neurol Sci 2005;238:47-52.

5. Kernan WN, Ovbiagele B, Black HR, Bravata DM, Chimowitz MI, Ezekowitz MD, et al. Guidelines for the prevention of stroke in patients with stroke and transient ischemic attack: A guideline for healthcare professionals from the American Heart Association/American Stroke Association. Stroke 2014;45:2160-236.

6. Kang S, Wu Y, Liu L, Zhao X, Zhang D. Association of the A1298C polymorphism in MTHFR gene with ischemic stroke. J Clin Neurosci 2014;21:198-202.

This is an open access article distributed under the terms of the Creative Commons Attribution-NonCommercial-ShareAlike 3.0 License, which allows others to remix, tweak, and build upon the work non-commercially, as long as the author is credited and the new creations are licensed under the identical terms.

\begin{tabular}{|l|l|}
\hline \multicolumn{2}{|c|}{ Access this article online } \\
\hline Quick Response Code: & Website: \\
\hline & www.ruralneuropractice.com \\
& \\
\end{tabular}

How to cite this article: Taveira I, Vicente C, Sobral S, Nzwalo H, Costa JE. Multiple inherited thrombophilias in a young patient with striatocapsular stroke. J Neurosci Rural Pract 2017;8:S154-5.

(C) 2017 Journal of Neurosciences in Rural Practice | Published by Wolters Kluwer - Medknow 